\title{
O NASCIMENTO DO "INTERNETÊS" E SUAS IMPLICAÇÕES NA COMUNICAÇÃO ESCRITA
}

\section{ARTIGO DE REVISÃO}

BESSA, Vicente Alberto Lima ${ }^{1}$

BESSA, Vicente Alberto Lima. O nascimento do "internetês" e suas implicações na comunicação escrita. Revista Científica Multidisciplinar Núcleo do Conhecimento. Ano 04, Ed. 09, Vol. 04, pp. 105-129. Setembro de 2019. ISSN: 2448-0959, Link de acesso: https://www.nucleodoconhecimento.com.br/letras/nascimento-do-internetes

\section{RESUMO}

O internetês é um sistema de linguagem taquigráfica, fonética e visual que visa facilitar e acelerar a comunicação escrita. Esse sistema se desenvolveu com o aparecimento das mensagens de texto (SMS/MMS) e tem evoluído com a tecnologia de comunicação. Sabe-se que muitas pessoas para escrever rápido, no cotidiano, passam a abreviar as palavras e acabam criando signos linguísticos, como o internetês. O presente estudo é uma revisão literária de cunho histórico que buscou investigar o surgimento do internetês, além de descrever as suas características, os seus aspectos positivos e negativos e apresentar opiniões dos educadores e dos especialistas na área sobre referido tema. Esse sistema grafo linguístico agiliza o processo de comunicação em tempo real, por isso é que existe um amplo uso de abreviaturas e ícones, além do fato das perguntas e respostas serem mais curtas e neste sentido ele realmente representa uma evolução no sistema de comunicação, mas só o tempo dirá os efeitos deletérios ou os benefícios que esta evolução causará.

Palavras-chave: internetês, escrita digital, novo dialeto.

\footnotetext{
${ }^{1}$ Especialização em Língua Portuguesa pelas Faculdades Integradas Simonsen e Licenciado em Letras pelas Faculdades Integradas Simonsen.
} 


\section{INTRODUÇÃO}

$\mathrm{Na}$ atualidade, é comum as pessoas se comunicarem através de WhatsApp, Telegram, Facebook Messenger, Line, Viber, Skype, WeChat etc. Todos eles são aplicativos que podem, em geral, permitir enviar mensagens e fazer chamadas gratuitas, integrado para mensagens de texto (SMS/MMS), chamadas de voz e vídeo, compartilhamento vários tipos de arquivos, como PDF, DOC, JPG, áudio, vídeo, fotos, entre outros.

Sabe-se que esses aplicativos de mensagens fazem parte da vida de milhões brasileiros e de mais de um bilhão de pessoas em todo o mundo, de acordo com levantamento da Mensageria no Brasil, promovido pela Panorama MobileTime e Opinion Box em agosto de 2018. (O Sul, 2018). Portanto, o mundo virtual se encontra nas mãos dos usurários de smartphones e tabletes e, por isso, a comunicação escrita, em áudio, vídeos e imagens tem se tornando cada dia mais frequente.

Percebe-se, então, que o computador, smartphone e tablete já fazem parte da vida de muitos brasileiros, os quais já se acostumaram as palavras que só existem na linguagem da informática, como deletar e scannear. Para acelerar ainda mais a comunicação escrita que surgiu em bate-papos, jogos, conversas entre usuários foi desenvolvida uma linguagem totalmente diferente: o internetês, que é uma linguagem taquigráfica, fonética e visual.

Os jovens com menos de 20 anos, principalmente aqueles frequentadores assíduos das salas de bate-papos, acabaram "aperfeiçoando" a língua, simplificando a grafia, criando símbolos e neologismos e aplicando a liberdade da fala à escrita. Eles passaram a se comunicar primordialmente através dessa linguagem virtual e dinâmica. Contudo, o que parecia uma brincadeira de criança começou a preocupar alguns professores da língua portuguesa, pois as conversas pela rede utilizam uma linguagem muito distante da chamada norma culta.

Em consequência desse fato, o assunto passou a ganhar notoriedade nas páginas dos jornais, na televisão e rádio. Também foi alvo de calorosos debates entre 
acadêmicos, escritores e jornalistas, especialmente depois que um canal de televisão pago, o Telecine Premium, resolveu legendar seus filmes com o internetês. (HANSEN, 2006; MARCONATO, 2006).

Essencialmente, o debate tem dividido os interessados entre os que são contra o internetês e os que são a favor. Em ambos os lados tem havido exageros e alarmistas de plantão. Os que são contra afirmam que "o uso dessa linguagem, com integral desobediência às regras cultas, não é próprio apenas dos brasileiros." (HAMZE, 2019, p.1). Ressaltam também que o internetês já começou a modificar os habituais meios de comunicação considerados como politicamente corretos. Portanto, dever-se-ia refletir as consequências desse acontecimento antes que ocorra uma descaracterização do português formal pela extrema e cada vez mais rápida fama da rede.

Os defensores, por outro lado, elogiam a capacidade dos jovens por criarem uma linguagem que pode agilizar o sistema de comunicação online. E para muitos esse sistema grafolinguístico é completamente inofensivo e seria apenas um instrumento de coesão entre uma comunidade jovem extremamente criativa. (FILHO, 2006 apud Lajolo, 2006). Por conseguinte, para muitos o internetês não passa de mais uma variedade linguística e o efeito sobre a sintaxe dos jovens pode não ser catastrófico como se imagina. Ele representa uma gíria de um grupo específico, da mesma forma como existe a gíria entre surfistas, skatistas, fankeiros etc.

Para os defensores do internetês, ele propicia a interação social e histórica, mas do que a simples transmissão de informação, pois "[...] por meio da língua em funcionamento o sujeito dialoga com o outro, constituindo se como sujeito da linguagem. (KOMESU e TENANI, 2009, p.639). Porém, o grande problema surge quando o uso dessa linguagem é feito em locais onde ela não é apropriada, como é o caso da escola. Para alguns educadores, como a Prof ${ }^{a}$ Eliana, está é uma situação muito fácil de ser solucionada. Ela declarou que:

Os adolescentes adoram, mas, como educadora, somente uso essa linguagem em comunicação instantânea, e temos um combinado: nas produções escolares deve ser 
usada a linguagem culta, pela razão que a escola é um espaço de aprendizagem, e onde os alunos aprenderão a escrever corretamente. Os adolescentes aceitam e usam cada linguagem no seu devido ambiente. (HAMZE, 2006 apud Eliana, 2006, p.1).

$\mathrm{Na}$ verdade, o internetês é uma linguagem que faz parte do imaginário de uma comunidade jovem e moderna. Além disso, saber escrever de duas maneiras seria bem melhor do que saber escrever de uma só, isto pode ser sinal de maior competência.

Portanto, o objetivo deste trabalho é investigar o surgimento do internetês, além de descrever as suas características, os seus aspectos positivos e negativos e apresentar opiniões dos educadores e dos especialistas na área sobre referido tema.

O presente estudo se justificou na medida em que permite a compreensão da influência do internetês na escrita dos usuários e suas implicações na comunicação. Para tanto, foi realizado um estudo de revisão de literatura com base histórica.

\section{REVISÃO DE LITERATURA}

\subsection{LINGUAGEM HUMANA}

A linguagem é um sistema composto por elementos que podem ser gestos, sinais, sons, símbolos ou palavras, que são utilizados para representar conceitos de comunicação, ideias, significados e pensamentos. Nessa acepção, linguagem aproxima-se do conceito de língua. A língua é um sistema convencionado pelo homem para se comunicar. Para tanto, ele criou regras, definiu como deve ser utilizada e qual a forma apropriada de recorrer a ela.

Devido a evolução humana, além da linguagem falada e escrita, o homem foi capaz de criar as linguagens de sinais, não só para melhorar a comunicação entre deficientes da áudio-comunicação, mas também para usá-las em situações especiais, como no teatro e entre navios ou pessoas que se encontram fora do alcance do ouvido, porém que se podem observar entre si. 
Com o advento da era da informática, o homem criou a linguagem de programação que é um conjunto de códigos usados em computação. A criatividade humana não se limitou apenas a linguagem técnica da informática, os jovens passaram a se comunicar em tempo real pela internet, e para acelerar a comunicação escrita surgiu o internetês.

O fenômeno do internetês é fácil de se explicar, pois as línguas evoluem, se diferenciam, se substituem, tomam empréstimos, dominam e são dominadas. As línguas não são estáticas embora exista um sistema de regras que as regem. Por exemplo, a língua portuguesa possui um sistema ortográfico que já evoluiu muito ao longo da história, como é o caso da palavra igreja que já teve dez grafias diferentes entre os séculos XII ao XV, foram elas: ygreja, eygreya, eygleyga, eigreia, eygreia, eygreyga, igleja, igreia, igreja e ygriga. (MORAES DE SOUZA, 2013).

Além da evolução ortográfica, a língua portuguesa também incorpora muitas palavras de origem estrangeiras, como é o caso de abajur, croquete, show etc. E a assimilação de novas palavras pode significar enriquecimento da língua e ela tem menos a perder do que se imagina. (FARACO, 2006). Mas apesar disso há aqueles que criticam o estrangeirismo, assim como existem aqueles que são contra o internetês. Entretanto em pleno século XXI a questão do estrangeirismo assim com a questão ortográfica ainda não se resolveu completamente, pois há muitos que ainda discutem sobre o uso das letras, dos acentos e até do hífen. Mais uma prova disso é o sucesso tão grande do internetês, pois já há quase sete milhões de usuários fluentes nesta nova forma de comunicação. (INAGAKI, 2006).

Outra prova da evolução da língua é que já existe um Langmaker, isto é, uma lista das várias línguas artificiais publicadas na Internet. (WIKIPÉDIA $\left.{ }^{\mathrm{b}}, 2006\right)$. As línguas artificiais ou construídas são línguas minoritárias, nelas se inclui o internetês, mas esta não é a única língua construída recentemente. O número de línguas artificiais, geralmente denominadas conlangs, uma palavra de origem inglesa - constructed language - tem aumentado a cada dia. No Brasil, existe um fenômeno chamado língua do pê, uma brincadeira com a língua e sua forma que já fez muito sucesso entre os jovens. 
Há também diversos sites na Internet que se dedicam ao aprofundamento da conlangs, incluindo listas e breves introduções a centenas ou mesmo milhares de línguas construídas. A maioria dos conlangers, pessoas que se dedicam ao fenômeno, fazem parte de uma lista de distribuição de e-mails: a CONLIST. Dessa forma é possível atualizar as informações e manter a vivacidade das novas línguas. (WIKIPÉDIA ${ }^{\mathrm{b}}$, 2019).

Tolkien, autor dos livros da série "O Senhor dos Anéis" criou várias línguas artificiais que são cada vez mais exploradas e conhecidas hoje em dia. Na lista de línguas construída por Tolkien se pode encontra: Quenya, Sindarin, Adûnaic, Entish e Khuzdûl. Essas línguas, de acordo com o próprio autor, foram criadas dentro de um mundo de aventuras para ter um contexto e um lugar próprio onde inseri-las. (WIKIPÉDIA ${ }^{\text {b }, ~ I b i d) . ~}$

Há também línguas que são bem aceitas socialmente, como é o caso do Esperanto criado por Zamenhof. Ele representa uma coletânea de múltiplos elementos de distintas línguas humanas cuja intenção foi de ser uma língua de fácil aprendizagem, de forma a proporcionar a toda a população humana uma forma mais fácil e democrática de se comunicar.

Contudo, antes do Esperanto surgiu o Silabário Sioux que é uma escrita organizada com caracteres do alfabeto arábico. Tem-se também o lídiche, língua oficial de Israel, que não é muito diferente do Silabário Sioux, pois se trata de uma escrita com caracteres do Silabário Hebraico os quais se prestam para escrever da direita para a esquerda.

A Novilíngua, no original Newspeak, foi criada por George Orwell para seu livro 1984, e era o idioma oficial da Oceania. Ela abolia os sinônimos e fundia as palavras, pois com a redução do idioma se tornava impossível pensar de forma diferente do que o Partido queria, isto na ficção do seu livro. A cada edição, o dicionário diminuía de tamanho, embora algumas palavras chegaram a ser adicionadas ao dicionário, mas apenas para que muitas deixassem de ser usadas. Por exemplo, a palavra "imbom" 
eliminava "ruim", "péssimo", "desagradável" etc. As palavras se tornaram obsoletas na mesma proporção que o pensamento se tornava obsoleto. (SILVINO, 2006).

A ficção de George Orwell se torna realidade caso se compare com a redução do idioma português. Este fenômeno é amplificado presentemente pelo uso do internetês, o português ultra-reduzido utilizado em programas de mensagens instantâneas, salas de bate-papo, celulares, fotologs, fóruns da Internet, no correio eletrônico e até nas redes de televisão.

Portanto, o internetês não representa uma língua impar artificial que a cada dia mais pessoas se tornam fluentes, mas é uma nova língua crivada de expressões como: " $v c$ quer tc?", "sua fotinha tah d++++, mtoooo xow, me adiciona no face!!!", ou "lôko o seu blog, naum ker trocar links?".

\subsection{O QUE É INTERNETÊS ?}

Existe o uso padrão das línguas, porém há, além disso, o diário apropriado ao contexto, uma vez que a intenção é comunicar. No entanto, o uso inadequado da língua salta aos olhos em um moderno meio de conversação: a internet. Configurase, nesse contexto, um novo emprego da língua. A internet gerou um ambiente de velocidade que simula a interação em tempo real, e se coloca em jogo o sincronismo das falas, como em uma conversa ao vivo. Desse modo, iniciam-se os cortes e se configura o internetês.

O internetês é uma linguagem que nasceu no ambiente da internet e é também cognominado como pt-sms. Este tipo de linguagem consiste numa codificação que emprega caracteres alfanuméricos a fim de propiciar uma simplificação informal da escrita (WIKIPÉDIAa , 2019). Para a psicóloga Rosa Maria Farah, da PUC de São Paulo, o internetês pode ser comparado a uma moderna gíria e conhecê-lo é como falar um idioma. (ECHEVERRIA, 2006). 
Primeiramente, o internetês era usado exclusivamente para IRC (Internet Relay Chat), porém esta linguagem passou a ser adotada em celulares, blogs, fotologs, fóruns da Internet, no correio eletrônico (e-mail) e demais apetrechos adolescentes.

O uso dessa forma de expressão grafolinguística aumentou nos últimos anos conquistando principalmente os adolescentes que passam horas na frente da Internet, em chats, blogs e comunicadores instantâneos a procura de interação mais dinâmica. Ele é uma das práticas possíveis da linguagem compartilhada via internet e é típica de pessoas que têm o propósito de se aproximarem física, afetiva e simbolicamente. (KOMESU, 2015). A prova do seu sucesso é que existiram cursos para o aprendizado desse sistema grafolinguístico. (LINKINSALES, 2006).

$\mathrm{O}$ internetês apresenta um código com palavras abreviadas onde a letra $\mathrm{X}$ e $\mathrm{K}$ parecem reinar absolutas. Abusa-se, também, da iconografia (letras em caixa alta, que significa estar gritando, por exemplo), além dos emoticons. Muitas vezes as palavras também podem aparecer como onda: iNtErNeTêS ou IxCrEvEr kOiZaX dExXe DjEiTuM.

\subsection{SIMPLIFICAÇÕES MAIS COMUNS NA LÍNGUA PORTUGUESA}

No internetês se busca uma simplificação das palavras ou expressões de forma a agilizar a digitação, como nos exemplos abaixo:

- "ou" transforma-se em "k" ou "ku", dependendo da palavra:

- aqui: aki;

- quem: kem;

- que $=q$ ou ke.

- "ch" transforma-se em "x":

- chocolate: xocolate;

- achar: axar.

A seguir, há uma lista com alguns dos termos e símbolos mais empregados nas conversações online. 


\begin{tabular}{|c|c|}
\hline- & significa menos \\
\hline+ & significa mais \\
\hline $4 U$ & sigla de for you, para você \\
\hline 9dades & novidades \\
\hline abc & abraço \\
\hline acuma? & como? \\
\hline AKI & aqui (1) \\
\hline aki & aqui (2) \\
\hline AWAY & $\begin{array}{l}\text { estar away significa estar online, mas não está na frente do } \\
\text { micro naquele momento, está fora }\end{array}$ \\
\hline axar & Achar \\
\hline B4 & sigla de before, antes \\
\hline beijaum & Beijão \\
\hline bijins & Beijinhos \\
\hline bjs & beijos \\
\hline BLZ & beleza (1) \\
\hline blz & beleza (2) \\
\hline $\mathrm{Blz}$ & beleza (3) \\
\hline BUAAA & choro, demonstração de tristeza (1) \\
\hline BUÁÁÁÁ & choro, demonstração de tristeza (2) \\
\hline BUEEE & choro, demonstração de tristeza (3) \\
\hline C & se ou também pode significar você \\
\hline $\mathrm{c} /$ & com (1) \\
\hline$c d$ & cadê (1) \\
\hline cê & você (1) \\
\hline chatear & conversar com alguém no CHAT \\
\hline CHUIF & choro, demonstração de tristeza (3) \\
\hline clap clap clap & aplausos, bravo, magnífico! \\
\hline $\mathrm{cm}$ & com (2) \\
\hline cool & Maneiro, legal; o mesmo que RULEZ \\
\hline craro! & claro! \\
\hline
\end{tabular}




\begin{tabular}{|c|c|}
\hline $\mathrm{D}+++++++++++++$ & Demais \\
\hline dd & Donde \\
\hline eh & $\dot{E}$ \\
\hline euzinha & eu \\
\hline falow & que significa adeus, até mais ou tchau (1) \\
\hline flw & falou \\
\hline FTW & sigla de for the win, que mostra apoio. \\
\hline Fuuuuuiiiiiiiiiiiiiiiiiii & maneira indelicada de sair sem se despedir, evasiva (covardia) \\
\hline gnt & gente \\
\hline hahaha & tipo de risada (1) \\
\hline hehehe & tipo de risada (2) \\
\hline hihihi & tipo de risada (3) \\
\hline HUMPF & demonstra desagrado \\
\hline ixi & exclamações (1) \\
\hline kbça & cabeça \\
\hline kct! & cacete \\
\hline kd & cadê (3) \\
\hline kdo & quando (1) \\
\hline ke & quem (1) \\
\hline kem & quem (2) \\
\hline kirida & querida \\
\hline kra & cara \\
\hline kto & quanto (1) \\
\hline kuatro & quatro \\
\hline kza & casa \\
\hline lammer & pessoa idiota \\
\hline LOL & $\begin{array}{l}\text { sigla de laughing out and loud ou lots of laughs, rindo alto ou } \\
\text { montes de risadas, dando uma gargalhada }\end{array}$ \\
\hline miguim & amiguinho \\
\hline lôko & louco \\
\hline mto & muito \\
\hline
\end{tabular}




\begin{tabular}{|c|c|}
\hline $\mathrm{n}$ & não (1) \\
\hline$\tilde{n}$ & não (2) \\
\hline naum & não (3) \\
\hline nen & não (4) \\
\hline nomidade & nome e idade \\
\hline oji ou hj & hoje \\
\hline oq & O quê? \\
\hline otoh & sigla de on the other han, por outro lado \\
\hline oxi & exclamações (2) \\
\hline $\mathrm{p} /$ & para \\
\hline putz & exclamações (3) \\
\hline Q & quem (3) \\
\hline q qi & o que quer \\
\hline qd & quando (2) \\
\hline qdo & quando (3) \\
\hline qm & quem (4) \\
\hline qto & quanto (2) \\
\hline RULEZ & maneiro, legal; o mesmo que COOL \\
\hline sacmskssssss & beijos (2) \\
\hline SNIFF & choro, demonstração de tristeza (4) \\
\hline SNIFF & choro (1) \\
\hline sniff!! & choro (2) \\
\hline sux & ruim \\
\hline$t+$ & que significa adeus, até mais ou tchau (2) \\
\hline tah & certo, tudo bem, e outras variantes \\
\hline tb & também (1) \\
\hline tbm & também (2) \\
\hline TC & teclar \\
\hline td & tudo \\
\hline TLÁ & até lá... \\
\hline tou & estou \\
\hline
\end{tabular}




\begin{tabular}{|l|l|}
\hline vc & você (2) \\
\hline vlw & valeu \\
\hline xamar & chamar \\
\hline xocolate & chocolate \\
\hline xow & show \\
\hline
\end{tabular}

Fonte: WIKIPÉDIAa, 2019.

\subsection{PALAVRAS E FRASES MUITO USADAS PELAS PESSOAS}

\begin{tabular}{|c|c|}
\hline $\begin{array}{l}\text { boralá que to } \\
\text { sonada }\end{array}$ & vamos embora que estou com sono \\
\hline bridadim kirido & obrigada querido \\
\hline chattear & conversar com outra pessoa no chat \\
\hline ctafim? & você está a fim? \\
\hline ctaí? & você está aí? (covardia) \\
\hline DCC & $\begin{array}{l}\text { Foto. Pede para a pessoa enviar uma foto pelo modo DCC } \\
\text { (comando que permite o envio e recebimento de arquivos } \\
\text { durante a conversa) }\end{array}$ \\
\hline eu lovo u & eu amo você \\
\hline FTW & sigla de for the win, que mostra apoio \\
\hline Kd vc? & Cadê você? \\
\hline $\begin{array}{l}\text { Ki ki tá } \\
\text { contecendo? }\end{array}$ & o que está acontecendo? \\
\hline me pinga & $\begin{array}{l}\text { Pede para que a pessoa dê um comando CTCP Ping para } \\
\text { saber em quanto tempo a mensagem vai e volta; comando } \\
\text { para saber a velocidade da conexão entre os dois usuários. }\end{array}$ \\
\hline mozezuiscristim & meu Jesus Cristo \\
\hline nomidade & perguntando o nome e a idade da pessoa \\
\hline otoh & sigla de on the other hand, por outro lado \\
\hline Pru6 & para vocês \\
\hline
\end{tabular}




\begin{tabular}{|c|c|}
\hline PVT-me & $\begin{array}{l}\text { sigla de pivate me, chamar uma pessoa para a sala particular, } \\
\text { para uma conversa privada }\end{array}$ \\
\hline SifU que já mifU & vai que eu já fui \\
\hline tc & é uma gíria para "conversar usando o teclado" \\
\hline teclakue? & fala comigo? \\
\hline tôka módó... & estou com muito dó... \\
\hline $\begin{array}{l}\text { vc pra mim é } \\
\text { problema seu! }\end{array}$ & expressão de solidariedade \\
\hline vodaboot travotudo & A minha mulher está chegando. Vou desligar \\
\hline
\end{tabular}

\subsection{EMOTICONS}

A linguagem dos internautas apresenta elementos muito peculiares denominados emoticons ou smileys. Estes são caracteres disponíveis no teclado que representam as emoções humanas e o tom de quem está falando.

A simbologia apresenta as suas particularidades, como por exemplo, o caráter :-) significa que a pessoa que está falando está feliz. Todavia, quando o internauta quer comunicar um sentimento de felicidade mais intenso, aumenta o número de fechamentos de parênteses, como pode ser observado abaixo.

\section{Puxa! Isso é muito bom :- ())))))}

\section{Que ótimo!!!! :-))))))}

Outra forma de expressar as emoções humanas na linguagem virtual é a utilização do "gritar". No internetês, utiliza-se caixa alta nos textos como em: "El! VOCÊ! PARE JÁ ONDE ESTÁ!". Em geral isso é considerado falta de educação ou significa que o interlocutor perdeu o controle sobre a razão.

É mister ressaltar que nem todos os internautas fazem uso desse recurso, embora a cada dia ele se torne mais habitual.

Abaixo se tem a relação dos símbolos mais comuns utilizados pelos internautas. 


\begin{tabular}{|c|c|}
\hline$\%+($ & espancado \\
\hline \&:-) & pessoa com o cabelo enrolado \\
\hline$(-)$ & precisando de um corte de cabelo \\
\hline$(-:$ & canhoto \\
\hline$(:-($ & estou muito triste \\
\hline$(:-)$ & careca \\
\hline$(:-\ldots$ & mensagem de partir o coração \\
\hline$(:-\mathrm{O}$ & assustado de chapéu \\
\hline$(:-x$ & mandando beijo (1) \\
\hline$:-x$ & mandando beijo (2) \\
\hline$\left.*^{*}\right)$ & drogado \\
\hline -l_ & gesto obsceno (1) \\
\hline. & gesto obsceno (2 \\
\hline /:-) & francês \\
\hline :-" & lábios franzidos \\
\hline :-\# & beijo (1) \\
\hline$:^{*}$ & beijo (2) \\
\hline$:-X$ & beijo (3) \\
\hline$:-\{$ & bigode (1) \\
\hline$:-\#)$ & bigode (2) \\
\hline :"'-( & inundação de lágrimas \\
\hline$:-($ & triste ou com raiva ( 1 ) \\
\hline$:($ & triste ou com raiva (2) \\
\hline$:^{\prime}-($ & chorando (1) \\
\hline$: \sim-($ & chorando (2) \\
\hline$:,-($ & chorando (3) \\
\hline$:-(\#)$ & usando aparelho dentário \\
\hline$:-(($ & muito triste \\
\hline$:-)$ & estou feliz \\
\hline$\left.:^{\prime}\right)$ & resfriado (1) \\
\hline$\left.:^{*}\right)$ & resfriado (2) \\
\hline
\end{tabular}




\begin{tabular}{|c|c|}
\hline$:-)^{\prime}$ & babando \\
\hline :-) & sorrindo (1) \\
\hline :) & sorrindo (2) \\
\hline$:-))$ & muito feliz \\
\hline :-)))) & estou gargalhando \\
\hline$:-[$ & vampiro (1) \\
\hline$:-\mid<$ & vampiro (2) \\
\hline$:-<$ & vampiro (3) \\
\hline$:-)=$ & vampiro (4) \\
\hline$:-)>$ & barbudo \\
\hline$:-) X$ & gravata borboleta \\
\hline :* & beijinho (1) \\
\hline$={ }^{*}$ & beijinho (2) \\
\hline$:-/$ & estou perplexo \\
\hline$:-1$ & indeciso (1) \\
\hline$: 1$ & indeciso (2) \\
\hline :/ & indeciso (3) \\
\hline$\because:-)$ & usuário de óculos \\
\hline$:-?$ & fumante de cachimbo \\
\hline :-@ & gritando \\
\hline :] & sorriso simples, "quadrado" ou sem-graça (1) \\
\hline$:-]$ & sorriso simples, "quadrado" ou sem-graça (2) \\
\hline$=]$ & sorriso simples, "quadrado" ou sem-graça (3) \\
\hline$\left.:^{\wedge}\right)$ & nariz grande ou nariz pontudo ou nariz quebrado \\
\hline$:-1$ & incerto ou hmmmph! \\
\hline$:-11$ & zangado \\
\hline$:-\}$ & olhando maliciosamente para alguém \\
\hline$:-\}+:-)=\left(\_\right)>$ & vamos tomar um chopinho \\
\hline :+) & nariz grande \\
\hline$:-0$ & estou impressionada \\
\hline$:-6$ & gosto azedo da boca \\
\hline
\end{tabular}




\begin{tabular}{|c|c|}
\hline$:-7$ & sorriso irônico \\
\hline :8) & porco \\
\hline$:-9$ & lambendo os lábios \\
\hline$\therefore-\mathrm{C}$ & muito infeliz \\
\hline$:-\mathrm{C}$ & queixo caído \\
\hline$:-\mathrm{D}$ & gargalhando ou sorriso grande ou risada ou muito contente (1) \\
\hline :D & gargalhando ou sorriso grande ou risada ou muito contente (2) \\
\hline$=\mathrm{D}$ & gargalhando ou sorriso grande ou risada ou muito contente (3) \\
\hline :-e & desapontado \\
\hline$:-\mathrm{i}$ & fumante (1) \\
\hline$:-Q$ & fumante (2) \\
\hline$:-\mathrm{j}$ & fumante sorrindo \\
\hline$:-0$ & Oh, não!! \\
\hline$:-0$ & chocado ou surpreso (1) \\
\hline$:-\mathrm{O}$ & chocado ou surpreso (2) \\
\hline$=0$ & chocado ou surpreso (3) \\
\hline :0) & nariz de palhaço (1) \\
\hline :0) & nariz de palhaço (2) \\
\hline$:-P$ & de língua para fora, expressando sarcasmo, dando língua (1) \\
\hline$:-p$ & de língua para fora, expressando sarcasmo, dando língua (2) \\
\hline$: P$ & de língua para fora, expressando sarcasmo, dando língua (3) \\
\hline :-S & confuso (1) \\
\hline$:-S$ & confuso (2) \\
\hline$=S$ & confuso (3) \\
\hline$:-\mathrm{t}$ & mal-humorado \\
\hline$:-T$ & lábios selados \\
\hline$:-\mathrm{V}$ & berro ou falando \\
\hline$:-x$ & "eu não devia ter dito isso" (ou beijo) \\
\hline ;-) & piscadela ou piscada (1) \\
\hline ;) & piscadela ou piscada (2) \\
\hline$?-)$ & olho roxo \\
\hline
\end{tabular}




\begin{tabular}{|c|c|}
\hline @.@ou@_@ & modo oriental de muito confuso \\
\hline$@\}-$ & enviando uma rosa para alguém \\
\hline$[:-)$ & usando headfones \\
\hline []'s & abraços \\
\hline$\hat{\wedge} \wedge$ & versão oriental de sorriso (1) \\
\hline$\wedge \wedge$ & versão oriental de sorriso (2) \\
\hline$\wedge \wedge$ & versão oriental de sorriso (3) \\
\hline$-,,{ }^{\wedge} \cdot \cdot^{\wedge},$, & espiando por cima do muro (1) \\
\hline - $\mathrm{m}\left(0 \_0\right) \mathrm{m}_{-}$ & espiando por cima do muro (2) \\
\hline$\{; \mathrm{V}$ & pato \\
\hline - -( & de madrugada \\
\hline H-) & dormindo \\
\hline $\mid:-)$ & sobrancelhas espessas \\
\hline H-] & robocop \\
\hline++ & versão oriental de chocado ou triste \\
\hline$<:-)$ & você fez perguntas bobas \\
\hline$<\mid-)$ & chinês \\
\hline$=:-)$ & punk \\
\hline$>:-)$ & sorriso malicioso, maldoso \\
\hline$>:-)$ & diabólico ou com chifres (1) \\
\hline$\}:-)$ & diabólico ou com chifres (2) \\
\hline$\neg$ & olhar de lado \\
\hline 3:-) & vaca \\
\hline 5:) & topete \\
\hline 5:-) & Elvis \\
\hline 8-) & usuário de óculos \\
\hline 8:) & gorila \\
\hline B-) & estou feliz e de óculos ou com óculos escuros \\
\hline Cl:-) & usando chapéu coco \\
\hline $\mathrm{d}:-)$ & usando boné \\
\hline$d:-P$ & de boné, dando língua \\
\hline
\end{tabular}




\begin{tabular}{|l|l|}
\hline i-) & detetive \\
\hline I-O & bocejando \\
\hline O:-) & santo ou "não fiz nada" \\
\hline O.O & versão oriental de assustado (1) \\
\hline O_O & versão oriental de assustado (2) \\
\hline O_o & estranhado algo (1) \\
\hline O_O & estranhado algo (2) \\
\hline O.o & estranhado algo (3) \\
\hline O.O & estranhado algo (4) \\
\hline R-) & óculos quebrados \\
\hline T.T & modo oriental de choro (1) \\
\hline T_T & modo oriental de choro (2) \\
\hline TT.TT & modo oriental de muito choro (1) \\
\hline TT_TT & modo oriental de muito choro (2) \\
\hline X-) & $\begin{array}{l}\text { com vergonha ou tímido ou estrábico } \\
\text { rindo, com os olhos fechados ou envergonhado (1) }\end{array}$ \\
\hline X) & rindo, com os olhos fechados ou envergonhado (2) \\
\hline XD & \\
\hline
\end{tabular}

Fonte: WIKIPÉDIAa 2019.

Outra forma de uso dos emoticons é a apresentação de imagens, inclusive em 3D (três dimensões) usadas em bate-papos. Existem programas de mensagens instantâneas que disponibilizam vários emoticons para seus usuários. Há também programas que permitem que o internauta crie os seus próprios emoticons e possam enviá-los quando quiser.

Os emoticons servem para ajudar na busca pela interatividade e por intimidade, desta forma há um processo de humanização da conversa. (BRYAN, 2006). Eles também servem para que o internauta mostre além das palavras seus sentimentos.

$\mathrm{Na}$ internet estão disponíveis gratuitamente milhares de emoticons. Eles podem ser de todos os tipos, formas e animações e são divididos nas seguintes categorias: bebês, Brasil, desenhos, emoticons, esportes, feminino, filmes e tv, fun, game, Hello 
Kitty, Internet, letras, love, manga, marcas, MessBrasil, mood, msn, msn plus, música, natureza, sites, status e outros tipos. Existe também a possibilidade de se escutar vozes ou sons durante a emissão dos emoticons. Hoje, elas são chamadas de figurinhas e são distribuídas através do Whatsapp.

A seguir estão expostos alguns exemplos de emoticons que podem ser encontrados na Internet.
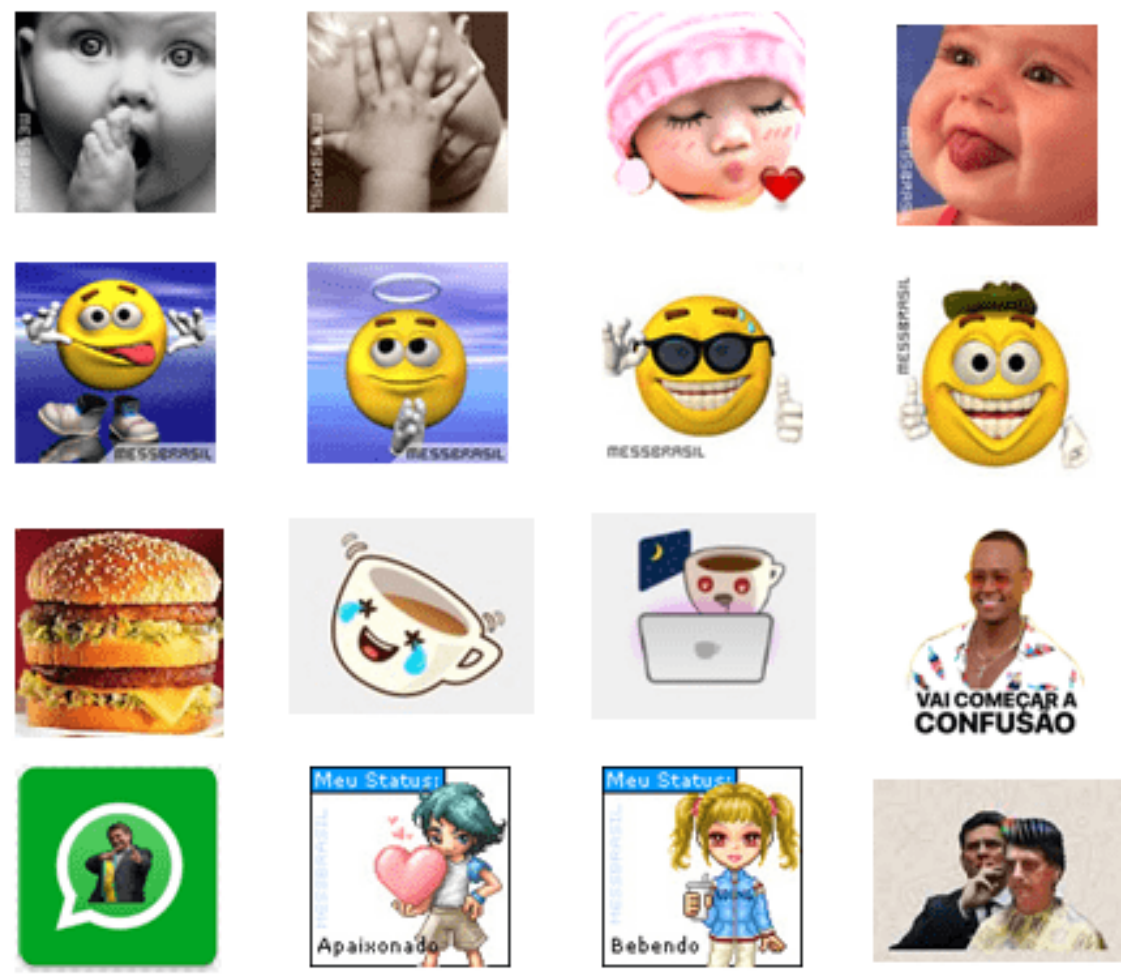

Fonte: Imagens diversas obtidas na Internet, 2019

Antigamente, o internauta que utiliza o MSN poderia digitar na janela de chat do MSN o código abaixo para aparecer o emoticon correspondente: 


\begin{tabular}{|c|c|c|c|c|}
\hline :-) ou :) & 3 & :d ou :-D & 0 & (mo) \\
\hline :-Oou :० & 8 & $:-P$ ou :p & 8 & (mp) \\
\hline ;-) Ou ;) & 68 & $:-1$ ou :( & 雨 & $(\infty)$ \\
\hline$:-5$ ou :s & ลู & $:-\mid$ ou : | & $\$$ & (um) \\
\hline :'( & 69 & $:-\$$ ou $: \$$ & 全陵 & (ip) \\
\hline (h) ou $(H)$ & 8 & :-@ou :@ & at & (ap) \\
\hline (a) ou $(A)$ & 항 & (6) & $\infty 00$ & (au) \\
\hline$:-=$ & 3 & $80 \mid$ & (6) & (so) \\
\hline $8-1$ & (⿶凵) & $\left.\hat{n}_{0}\right)$ & $\Leftrightarrow$ & (pi) \\
\hline$:-*$ & 40 & $+o l$ & $\sin$ & (bah) \\
\hline$: \wedge$ & 6 & $\left.*_{-}\right)$ & 효 & $(n)$ \\
\hline$<: 0)$ & 69 & 8-) & 8 & (m) ou (M) \\
\hline$|-\rangle$ & $b$ & $(c)$ ou $(C)$ & (3) & (o) ou (0) \\
\hline$(y)$ ou $(n)$ & 8 & $(\mathrm{n})$ ou $(\mathrm{N})$ & है & ()$\left.^{*}\right)$ \\
\hline (b) ou (B) & $\$$ & (d) ou (D) & $\delta$ & (8) \\
\hline$(x)$ ou $(x)$ & * & $(z)$ ou $(z)$ & (3) & (S) \\
\hline (f) & 8 & (3) & $\Delta$ & (e) ou (E) \\
\hline$:-[$ ou :[ & 急 & $(\wedge)$ & ${ }_{A} P_{L}$ & (?) \\
\hline (I) ou (L) & 98 & $(u)$ ou $(U)$ & ค & $(r)$ ou $(R)$ \\
\hline (k) ou (K) & 夈 & (g) ou (G) & 㺖 & $\Leftrightarrow)$ \\
\hline$(f)$ ou (F) & a) & $(w)$ ou $(W)$ & $B$ & $(\%)$ \\
\hline$(p)$ ou $(P)$ & 88 & $(\sim)$ & $\approx$ & $(t u)$ \\
\hline (@) & (2) & $(\&)$ & $g$ & $(x)$ \\
\hline$(t)$ ou $(T)$ & $8:$ & (i) ou (I) & $6 g_{2}$ & (brb) \\
\hline (pl) & $\notin$ & (II) & 3 & $(y n)$ \\
\hline (st) & s & (li) & Q日e & (h5) \\
\hline (nah) & 8 & (ci) & & \\
\hline
\end{tabular}

Fonte: Messbrasil, 2006 


\subsection{SOTAQUES, GÊNERO E FAIXA ETÁRIA}

No Brasil é possível se perceber variações linguísticas do português que se desenvolveram através dos anos, como por exemplo: as falas do carioca, do baiano, do gaúcho, do nordestino, do capixaba, do mineiro etc.

Também vale notar que a linguagem virtual é tão rica que foi possível se estabelecer um regionalismo, isto é, o internetês também permite revelar o sotaque da pessoa que o utiliza. A linguagem virtual se caracteriza por um conjunto de abreviações de sílabas e simplificações de palavras que leva em conta a pronúncia e a eliminação de acentos, por isso pode-se diferenciar os sotaques.

No internetês são utilizadas abreviações fonéticas ("naum" = "não") e não etimológicas ("pneumático" vira "pneu", mas mantém o radical pneu = ar), pois existe a necessidade de se escrever em tempo real, ou seja, o "falante" para pode conversar com muitas pessoas ao mesmo tempo, mas para tanto precisa escrever com o mínimo de caracteres, de forma curta e rápida. A carência de acentuação gráfica e pontuação surgiu devido ao fato de que muitos servidores não estão aptos a reconhecer os sinais, logo a mensagem seria destruída ou convertida em símbolos ininteligíveis e não padronizados.

Fato curioso é que a grafia "naum" é equivalente à representação fonológica dos ditongos nasais sugerida pelo linguista Joaquim Mattoso Câmara. Mattoso não considerava que no português existissem legítimas vogais nasais. $\mathrm{Na}$ análise tradicional, considera-se que vocábulos como não, leão ou salão apresentam um ditongo nasal, no qual está presente a vogal /ã/, grafada com um til. Para Mattoso, contudo, não se trata de uma vogal nasal, mas de uma vogal oral seguida de uma consoante nasal. Mais ou menos como na grafia adotada nas palavras com ou partiram, por exemplo.

Seguindo-se a teoria de Mattoso Câmara, a transcrição fonológica para os ditongos grafados -ão equivaleria à sequência /awN/. Compare-se com o internetês, que escolhe naum, e ver-se-á que as diferenças são de detalhe: $\mathbf{u}$ em vez de $\mathbf{w}$, e $\mathbf{m}$ no 
lugar de $\mathbf{N}$, escolhas que, em contrapartida, valorizam as opções ortográficas correntes. (POSSENTI, 2006, p. 30).

É fácil observar que a escrita do internetês valoriza as consoantes em detrimento das vogais, como no caso de blz $(\mathbf{b}=\mathrm{be}, \mathbf{I}=$ lê, $\mathbf{z}=\mathrm{za})$ e $\mathbf{k b e c ̧ a}(\mathbf{k}=\mathbf{k a}, \mathbf{b}=\mathrm{be}$, ça $=$ ça $)$. Logo, infere-se que este sistema gráfico não é aleatório.

As adolescentes também podem ser facilmente reconhecidas, visto que apresentam como característica a utilização de expressões que significam doçura e inocência, como o em meux amigux, que lê-se meusch amigusch, o qual é conhecido no Brasil como miguxês. O termo é proveniente de miguxa, variante de "amiga", que é uma forma polida usada no tratamento entre duas adolescentes em mensagens trocadas pela internet ou em blogs.

Como características mais particulares do miguxês, em relação ao que se habitua nomear de internetês, há a substituição do "o" em final de palavras por "u" e do "e" por "i", a grafia genérica das fricativas dentais surdas como " $\mathrm{x}$ " e a permuta do "r" intervocálico por "I". O miguxês diferentemente do internetês não tem como propósito abreviar palavras para facilitar a escrita, mas, sim, enfeitar as palavras para thes dar uma aparência mais pueril. Alguns usuários cariocas e lisboetas substituem o ditongo "ou" por "ô". Outra permuta corriqueira entre os brasileiros é a dos "I" finais por "u".

O miguxês imita na forma escrita a forma falada conhecida como tatibitati. Este tipo de recurso é bastante usado para a comunicação com bebês e crianças. Acredita-se em geral que recorrência de um tom de voz mais fino e com troca das letras, anima, estimula e faz com que a criança se sinta amparada, menos irritada e mais confiante com seu interlocutor, embora alguns educadores argumentam que essa forma de falar com crianças possa atrasar seu aprendizado da linguagem correta.

Um caso particular é lol ou LOL, que significa rir bem alto ou gargalhar que deriva do acrónimo inglês laugh out loud. Para alguns, o lol parece com uma pessoa com os braços levantados, ou ainda uma boca aberta rindo. No Brasil, usa-se hahuaheuahua, aUAheUHEAUehaeuhaeuAH, KKKKKKKKKKKK ou rssssssn, 
além de diversas variações, bem como o eheheh, do mesmo modo com sentido de riso, este último é comum tanto no Brasil quanto em Portugal.

Uma característica do sotaque dos internautas do norte de Portugal é a substituição, por vezes, do "v" por "b". Já os da Beiras de Portugal, assim como nordestinos no Brasil, substituem os "s" e "c" (antes de 'e' e 'i') por "x", reproduzindo sua característica dialetal. (BRYAN, 2006).

\subsection{ASPECTOS NEGATIVOS DO INTERNETÊS}

No programa da TVE, o Observatório da Imprensa, de 29 de março de 2006 foi debatida se a linguagem da internet prejudicaria ou não a língua portuguesa. Discutiram-se também sobre o empobrecimento do português, o uso exagerado dos bordões na imprensa e das simplificações. Estiveram presentes debatendo sobre 0 internetês, os seguintes intelectuais: o jornalista Alberto Dines, apresentador do programa; o escritor Deonísio da Silva; e a escritora gaúcha Martha Medeiros. Todos foram contrários ao novo dialeto eletrônico. (HANSEN, 2006.)

Para Deonísio da Silva, o internetês é uma verdadeira degradação da língua, um verdadeiro atentado infame a ela, "besteirol" e o classifica como um "assassinato a tecladas" da língua portuguesa. Ele também analisou o assunto com bom senso e acrescentou que nunca se escreveu tanto como nesses tempos de correspondências eletrônicas, porém para ele estão "botando os carros na frente dos bois". Isso significa que os jovens possuem acesso à internet e ao celular, todavia não à norma culta da língua escrita. (HANSEN, Ibid.)

Para abreviar, o escritor reitera que o internetês representa um grave sintoma da falência do sistema educacional, que por sua vez, promove a supressão das crianças e adolescentes ao mundo letrado ao qual só poucos têm acesso.

Corroborando, Alberto Dines assegura que o novo idioma representa um rebaixamento da língua, um "nivelar por baixo". Já Martha Medeiros concluiu, citando o escritor português José Saramago, Prêmio Nobel de Literatura, que salientou que, 
em breve, as pessoas estarão se comunicando com grunhidos, como os homens das cavernas. E relatou que Saramago nem se referia à internet, mas ao fato de que, há apenas cinco décadas, a língua era falada e escrita de maneira mais admirável e rica, por nossos antepassados. (HANSEN, op. cit.)

O autor do "Manual de Redação" do jornal O Estado de S. Paulo, Eduardo Martins, é outro que analisa o fenômeno linguístico com reservas, pois para ele o aprendizado da escrita depende da memória visual. Ele ressalta que muitas pessoas quando esquecem a grafia da palavra a escrevem várias vezes para tentar, visualmente, lembrar dela. E se os jovens ainda em formação forem bombardeados por diferentes grafias tenderão à dúvida. (MARCONATO, 2006).

Durante o programa foi feita uma enquête com a seguinte pergunta: as licenças de linguagem na internet empobrecem a língua portuguesa? O resultado foi que $72 \%$ disseram que sim e apenas $28 \%$ que não. (TV E BRASIL, 2006). Portanto, o internetês para a maioria das pessoas pode influenciar de forma negativa o idioma português devido ao seu alto poder de penetração nos meios de comunicação.

No Noticiário Geral, Elio (2006) satirizou o internetês no seu artigo "Nossa sugestão para o internetês", publicado online em 03 de dezembro de 2005. Ele afirmou de forma irônica que foi criado um programa para resolver a dificuldade da do brasileiro com a gramática. E em vez de melhorar a qualidade de ensino no país se pode facilitar as coisas, pois o português é muito difícil. Veja a solução proposta:

Para não assustar os poucos que sabem escrever, nem deixar mais confusos os que ainda tentam acertar, faremos tudo de forma gradual.

No primeiro ano, o "Ç" vai substituir o "S" e o "C" sibilantes, e o "Z" o "S" suave.

Peçoas que açeçam a internet com freqüênçia vão adorar, prinçipalmente os adoleçentes. O "C" duro e o "QU" em que o "U" não é pronunçiado çerão trokados pelo "K", já ke o çom é ekivalente. Iço deve akabar kom a konfuzão, e os teklados de komputador terão uma tekla a menos, olha çó ke koiza prátika e ekonômika. 
Haverá um aumento do entuziasmo por parte do públiko no çegundo ano, kuando o problemátiko "H" mudo e todos os acentos, inkluzive o til, seraum eliminados. $\mathrm{O}$ "CH" çera çimplifikado para "X" e o "LH" pra "LI" ke da no mesmo e e mais façil. Iço fara kom ke palavras como "onra" fikem $20 \%$ mais kurtas e akabara kom o problema de çaber komo çe eskreve xuxu, xa e xatiçe. Da mesma forma, o "G" ço çera uzado kuando o çom for komo em "gordo", e çem o "U" porke naum çera preçizo, ja ke kuando o çom for igual ao de "G" em "tigela", uza-çe o "J" pra façilitar ainda mais a vida da jente.

No terçeiro ano, a açeitaçaum publika da nova ortografia devera atinjir o estajio em ke mudanças $\mathrm{m}$ ais komplikadas seraum poçiveis. O governo vai enkorajar a remoçaum de letras dobradas que alem de desneçeçarias çempre foraum um problema terivel para as peçoas, que akabam fikando kom teror de soletrar. Alem diço, todos konkordaum ke os çinais de pontuaçaum komo virgulas dois pontos aspas e traveçaum tambem çaum difiçeis de uzar e preçizam kair e olia falando çerio ja vaum tarde.

No kuarto ano todas as peçoas ja çeraum reçeptivas a koizas komo a eliminaçaum do plural nos adjetivo e nos substantivo e a unificaçaum do $U$ nas palavra toda ke termina kom L como fuziu xakau ou kriminau ja ke afinau a jente fala tudo iguau e açim fika mais faciu. Os karioka talvez naum gostem de akabar com os plurau porke eles gosta de eskrever xxx nos finau das palavra mas vaum akabar entendendo. Os paulista vaum adorar. Os goiano vaum kerer aproveitar pra akabar com o $D$ nos jerundio mas ai também ja e eskuliambaçaum.

No kinto ano akaba a ipokrizia de çe kolokar $\mathrm{R}$ no finau dakelas palavra no infinitivo ja ke ningem fala mesmo e tambem $\mathrm{U}$ ou I no meio das palavra ke ningem pronunçia komo por exemplo roba toca e enjenhero e de uzar $\mathrm{O}$ ou $\mathrm{E}$ em palavra ke todo mundo pronunçia como $\mathrm{U}$ ou I, i ai im vez di çi iskreve pur ezemplu kem ker falar kom ele vamu iskreve kem ke fala kum eli ki e muito milio çertu ? os çinau di interogaçaum i di isklamaçaum kontinuam pra jente çabe kuandu algem ta fazendu uma pergunta ou ta isclamandu ou gritandu kom a jenti e o pontu pra jenti sabe kuandu a fraze akabo. 
Naum vai te mais problema ningem vai te mais eça barera pra çua açençaum çoçiau e çegurança pçikolojika todu mundu vai iskreve sempri çertu i çi intende muitu melio i di forma mais façiu e finaumenti todu mundu no Braziu vai çabe iskreve direitu ate us jornalista us publicitário us blogeru us adivogado us iskrito i ate us pulitiko i u prezidenti olia ço ki maravilia. (ELIO, 2006, p. 1).

Elio (2006) em seu artigo tentou demonstra o comprometimento que a língua portuguesa teria se todos adotassem o internetês como grafia oficial. Mas é claro que para as pessoas que não dominam essa forma grafolinguística não fará muito sentido o texto. Todavia, para os internautas seria como se estivessem escrevendo em inglês, por exemplo.

É fato que algumas pessoas não conseguem dissociar o internetês da escrita formal e o utilizam inclusive na escrita em papel. É aí que talvez resida o maior problema: o fato de tratar-se de um registro escrito. Há uma imensa diferença entre os registros oral e escrito das línguas, pois o primeiro é temporário e espontâneo, porém o outro é permanente e elaborado. É possível que o uso continuo do internetês por crianças em fase de alfabetização possa prejudicar, no mínimo, a ortografia. E aí está o problema: o fato do internetês ser usada por escrito e não oral.

Para Marcelo Tas, um dos criadores do premiado "Castelo Rá-Tim-Bum", da TV Cultura, e da Mesa de Etimologia da "Estação da Luz da Nossa Língua" e apresentador do "Saca-Rolha", no canal 21, o uso do internetês pode sinalizar a carência de diálogo contemporâneo entre o adulto e o jovem e não apenas um cacoete de linguagem. Ele acredita que o "problema" do internetês tem sido superdimensionado ou mal enquadrado. (MARCONATO, op. cit).

É preciso ressaltar que o jovem criou um código para se diferenciar do mundo adulto, mas não deixa de depreciar o português, pois vicia. Contudo é mister que essa linguagem seja compreendida pelos adultos. (BRYAN, 2006 apud Strum, 2006). 
É provável que o dialeto eletrônico ainda gere mais polemica, porém alguns afirmam que devido ao seu reduzido léxico é mais fácil que o debate, assim como a própria vida do novo dialeto, não seja capazes de ir muito longe. (HANSEN, op. cit.).

\subsection{ASPECTOS POSITIVOS DO INTERNETÊS}

No Brasil, o internetês é utilizado por cerca de sete milhões de usuários e, não obstante de ser mais corriqueiro entre as crianças e os jovens, espalha-se em passo acelerado por toda a população. (INAGAKI, 2006). Ele representa mais um dos usos da língua adequado ao contexto de agilidade e simulação. É característico de um grupo de utentes que possuem a sua cultura e seu estilo próprios.

O internetês apresenta-se como um modo de aplicação da Língua, marcado por supressões, adequações, criação de um código próprio (da tribo/ dos usuários), mas, sobretudo por uma simulação da oralidade. Simula-se uma conversa falada, não escrita. Atesta isso a preocupação em expressar risadas e em enfatizar partes de palavras para dar a ideia de entonação mais forte: hehehehe; muuuuuitoooo. (DIESEL, 2006, p.1)

Ao se conversar com alguém no meio virtual, o internauta pode brincar com as palavras, o que se torna inteiramente apropriado escrever de maneira econômica, pressupondo a representação sonora daquilo registrado por escrito. Isto é necessário para se ter a impressão de estar escutando e falando. É por isso que a ênfase sonora, a noção de entonação das palavras, também aparecem, pois são valiosas à simulação da conversa. Vivência-se dessa forma a língua através do registro por escrito da expressividade oral. (DIESEL, Ibid).

Há pessoas que não acreditam que a linguagem intermediada pela internet seja vista como uma ameaça à produção impressa (livros, jornais, revistas) ou um presságio de criar uma geração de analfabetos. Atualmente, este novo espaço de leitura e escrita mostra uma forma criativa, com características ainda mais livres de construções literárias e que transcende uma marcação analógica de tempo e espaço. 
O internetês pode não representar uma ameaça ao idioma como no passado a grafia dos telégrafos ("vg" para vírgula) ou o caipirês de Chico Bento, personagem de Mauricio de Sousa, não o fizeram. Sírio Possenti, professor de linguística da Unicamp, assegura que não existiria fator de risco. Uma coisa é a grafia; outra, a língua. Não há linguagem nova, só técnicas de abreviação no internetês. As soluções gráficas são até interessantes, pois a grafia cortada é a vogal. A palavra "cabeça", por exemplo, vira "kbça", e não "aea". A primeira forma contém os fonemas indispensáveis ao entendimento. (MARCONATO, op. cit, p. 24)

Uma das justificativas daqueles que são contra o internetês é que ele deturpa a ortografia das palavras, o que as tornam incompreensíveis. Mas ao contrário da língua que é um processo natural, a ortografia é artificialmente construída pelo homem. E a sua alteração não promove mudança nas estruturas gramaticais da língua. Fato é que há textos escritos com sistemas ortográficos antigos que podem ser facilmente compreendidos pelo leitor, como por exemplo: chimica, physica, mathematica, philosophia, pharmacia homoepathica, rgreja, egypto, scenographia etc. (BAGNO, 2005).

Para BAGNO (2006) todos nós temos que nos conscientizar de que toda língua muda e varia. Conseqüentemente, o que atualmente é visto como correto pode já ter sido errado no passado.

Um exemplo: no português medieval existia um verbo leixar (que aparece até na carta de Pero Vaz de Caminha ao rei D. Manuel I). Com o tempo, esse verbo foi sendo pronunciado deixar, porque [d] e [l] são consoantes aparentadas, o que permitiu a troca de uma pela outra. Hoje quem pronunciar leixar vai estar cometendo um "erro" (vai ser acusado de desleixo), muito embora essa forma seja mais próxima da origem latina, laxare (campare-se, por exemplo, o francês laisser e o italiano lasciare). Por isso é bom evitar classificar algum fenômeno gramatical de "erro": ele pode ser, na verdade, um indício do que será a língua no futuro. (BAGNO, 2006, p. 143-144).

Pode-se constatar que para muitos lingüistas o internetês não é uma deturpação da língua, mas uma variedade linguística e uma forma de agilizar a comunicação. Este 
fato foi confirmado na enquête realizada no primeiro dia do III Congresso Iberoamericano EducaRede, em 31 de maio de 2006. Este é mais um dado estatístico que corrobora para desmistificar a ameaça à Língua Portuguesa.

\begin{tabular}{|l|l|l|}
\hline Como você considera o internetês ? & Percentagem & № de votos \\
\hline uma variedade linguística & 16.73 & 315 \\
\hline uma ameaça à Língua Portuguesa & 28.68 & 540 \\
\hline um modismo & 10.99 & 207 \\
\hline uma forma de agilizar a comunicação & 43.60 & 821 \\
\hline Total de participantes (usuários do EducaRede) & $\mathbf{1 0 0}$ & $\mathbf{1 8 8 3}$ \\
\hline
\end{tabular}

Fonte: HAMZE, 2006 apud Bertocchi, 2006

Um dos adeptos do internetês é o imortal Ledo Ivo, poeta de 80 anos, membro da Academia Brasileira de Letras que aprova essa nova língua fonética e econômica.

Em entrevista ao Fantástico que foi ao ar no dia 24 de outubro de 2005, na Rede Globo, Ledo Ivo afirmou que o internetês é uma linguagem cifrada e que ele não tem preferência por uma ou outra forma de expressão, visto que é mister que uma pessoa seja, no mínimo, bilíngüe, fato dito em tom de brincadeira. Explanou ainda que o internetês tem uma íntima relação com as construções poéticas ao afirmar que: "É praticamente a mesma linguagem que eu uso, porque a linguagem de poeta e a linguagem de criança é a mesma coisa." (LEDO IVO, 2005 in Bloguinho traz o "internetês para o universo das historinhas da Turma da Mônica, 2006).

Para Patrícia Behar, coordenadora do Núcleo de Tecnologia Digital Aplicada à Educação, da Universidade Federal do Rio Grande do Sul, o internetês estimulou o hábito de escrever e isso pode ser considerado bom sob o ponto de vista educacional. (ECHEVERRIA, 2006).

O professor titular de língua portuguesa na Universidade de São Paulo e um dos especialistas que ajudaram a criar a Estação da Luz da Nossa Língua, Ataliba de Castilho, vislumbra o internetês como parte da metamorfose natural da língua. Ele 
acredita ainda que o internetês possa auxiliar a reduzir os excessos da ortografia, uma vez que como toda palavra é contextualizada pelo falante, poder-se-ia dispensar muitos acentos.

Com a internet, a linguagem segue o caminho dos fenômenos da mudança, como o que ocorreu com "você", que se tornou o pronome átono "cê". Agora, o interneteiro pode ajudar a reduzir os excessos da ortografia, e bem sabemos que são muitos. Por que o acento gráfico é tão importante assim para a escrita? Já tivemos no Brasil momentos até mais exacerbados por acentos e dispensamos muitos deles. Como toda palavra é contextualizada pelo falante, podemos dispensar ainda muitos outros. O interneteiro mostra um caminho, pois faz um casamento curioso entre oralidade e escrituralidade. (MARCONATO, 2006 apud Castilho, 2006, p.29).

A professora de língua portuguesa, Úrsula Diesel da UniCEUB, também acredita que o internetês possa ser uma alavanca para mudanças. Ela ressalta que talvez os jovens brasileiros nunca tenham escrito tão espontaneamente como agora com o internetês. Este pode representar uma incomensurável oportunidade de repensar o aprendizado da língua, de tornar o processo de seu entendimento algo vivo. Ela ainda salienta que:

Imagino as aulas de Língua Portuguesa aproveitando as conversas salvas para entender por que se diz assim e não assado o que poderia funcionar melhor e mostrar qual é a diferença entre os registros, valorizando o papel da língua e não só a língua do papel. (DIESEL, op. cit, p.1).

Não se sabe se o internetês, no futuro, pode se tornar uma comunicação mais eficiente ou até mesmo se especializar para um jargão complexo, que, em vez de unir as pessoas em menor tempo, estimule o isolamento dos internautas e a exclusão dos leigos. Todavia, para o Prof ${ }^{\circ}$ Castilho será a internet que fará a mudança necessária na língua e não a reforma ortográfica.

A TVE exibe semanalmente um programa chamado de Observatório da Imprensa e promoveu o debate a respeito do internetês. Estiveram presentes no debate defendendo o internetês, os seguintes intelectuais: o poeta Ledo Ivo, membro da 
Academia Brasileira de Letras; a professora Marisa Lajolo, escritora e pesquisadora do Instituto de Estudos da Linguagem da Universidade de Campinas (Unicamp), autora de dezenas de obras e artigos, como "Do mundo da leitura para a leitura do mundo (Ed. Ática) e uma das maiores especialistas brasileiras em leitura e escrita; e o professor Sérgio Nogueira, que comanda um programa na Rede STV sobre língua portuguesa. (HANSEN, op. cit).

Para a escritora Marisa Lajolo o uso do linguajar cibernético caracteriza a criatividade dos adolescentes em instituir um código próprio, que reforça a identidade dos mesmos. Acredita que a nova linguagem usada pelos jovens para se comunicarem entre si está promovendo um "surto de poliglotas". Os internautas tornam-se poliglotas pela sua capacidade de se expressar de modo díspar com seus pais, professores e com os demais interlocutores da comunidade. (HANSEN, op. cit.)

Já o Prof. Sérgio Nogueira acredita que esse é um fenômeno natural e recomendou os professores a não se abismarem, mas procurarem conhecer a linguagem. Para ele, o problema maior a ser atacado pelos educadores é mesmo o domínio da linguagem padrão. (HANSEN, op. cit.)

O imortal Ledo Ivo mais uma vez se reportou ao assunto e manteve o seu apoio ao dialeto eletrônico, como assim o batizou. Para o acadêmico se está diante de um fenômeno lingüístico e cultural que comprova que a língua é viva, por isso tem capacidade de se transformar através das gerações. (HANSEN, op. cit.)

Existem também pessoas fanáticas pelo dialeto eletrônico e que acreditam que ele veio revolucionar a língua portuguesa. Eles chegam a oferecer um curso de língua de internetês, no qual estão traduzidas as principais expressões da "língua" num "dicionário". (LINKINSALES, 2006). O dicionário de internetês é constituído por um conjunto de palavras e expressões de origem inglesa, além de várias abreviações e palavras criadas que espelham o som das sílabas pronunciadas. Não é difícil entendêlo e qualquer pessoa que seja alfabetizada e que possua conhecimento de conceitos básicos de inglês será capaz de decifrar o código. 


\subsection{FILMES EM INTERNETÊS}

O sucesso do internetês é tão grande que acabou sendo aderido pela Rede Globo através da Globosat, um canal de assinatura. Toda terça-feira é dia de sessão cyber movie de cinema e os filmes estrangeiros são legendados em internetês. Nestes filmes são exibidas legendas com abreviações como "aki" (aqui), "cmg" (comigo) e blz (beleza) e aberrações como kerer (querer), 9dades (novidades) e xamar (chamar). (SILVINO, 2006; TV E BRASIL, 2006; O WEBLOG DA ACGLOBA, 2006).

O publico alvo da Globosat é constituído por milhares de pessoas, principalmente préadolescentes e jovens, os quais apóiam e utilizam com muita freqüência essa nova língua. Contudo, a nova sessão também atraiu a ira de diversos telespectadores que não aceitam a nova linguagem. Apesar de tudo, a Rede Globo garantiu a prosseguimento da programação. (TV E BRASIL, Ibid).

Não vou criticar quem escreve em internetês, apenas acredito que a brincadeira deveria parar na tela do computador. Não concordo com a atitude do Telecine de levar para suas legendas um código de linguagem tão pobre e infantil. Pessoas que não compreendem o idioma em que o filme é falado dependem da legenda para acompanhar o filme. É um trabalho extremamente difícil traduzir as nuances da linguagem falada e as peculiaridades de um idioma para o outro. Com a sessão cybermovie, qualquer profundidade no diálogo dos filmes é perdida e o telespectador monolíngue acaba ficando com uma impressão comprometida da trama. Entre os milhares de assinantes da Net/Sky quantos preferem ver seus filmes em internetês? Poucos, eu aposto. Fica aqui meu protesto. (O WEBLOG DA ACGLOBA, op. cit, s/p.).

Há críticos que afirmam que a Globosat resolveu legendar seus filmes apenas movido pela necessidade mercadológica de atrair a audiência jovem com o "internetês". $\mathrm{Na}$ mídia impressa também existem pessoas se manifestando contra a proposta dos filmes legendados em internetês, como por exemplo: a escritora gaúcha Martha Medeiros. Ela escreveu, na sua coluna da Revista O Globo, 20 de março de 2005, sobre o assunto e mostrou estar espantar com a adoção do dialeto no lançamento do 
Cyber Movie. Para ela, esse é um sinal de lamentável e vertiginosa decadência da língua portuguesa. (HANSEN, op. cit).

\subsection{REVISTAS EM INTERNETÊS}

Maurício de Sousa traz para o universo das histórias em quadrinhos o dialeto da língua portuguesa recheado de expressões como blz, chat, emoticon e a indefectível risada usada por nove entre dez internautas adolescentes, $K K K K K K K K K K K$.

A capa da edição no 221 da Revista Cebolinha da Turma da Mônica anuncia um novo personagem, o Bloguinho. Este personagem é um garoto aficionado por Internet e que se comunica com os outros através do internetês. (INAGAKI, op. cit; Bloguinho traz o “internetês para o universo das historinhas da Turma da Mônica, 2006).

Acredita-se que assim como o personagem Cebolinha, embora trocando o $\mathbf{r}$ pelo I, obteve sucesso e aprovação, o novo personagem também será bem recebido, como tem sido o internetês.

Bloguinho é o irmão mais novo do TV Luisão, personagem que não sai por nada da frente da televisão. Em sua estreia, Bloguinho apresenta aos leitores uma volumosa salada de expressões "internéticas", permutando às suas falas com palavras como nick, chat, blz e emoticon, entre outras, até então de uso reservado dos internautas. Cebolinha e Cascão foram os personagens escolhidos para dar as boas-vindas ao novo amiguinho. Ambos quase ficam "malucos" com tamanha novidade. Cebolinha acredita que a língua seja tão incompreensível, diferente e estranha que pergunta se é grego. O outro personagem Cascão desejando demonstrar conhecimento responde: “Ai Cebolinha! Não me faça passar vergonha. Tá na cara que é francês”!

Fonte: O personagem Bloguinho e a capa da edição nº 221 da Revista Cebolinha da Turma da Mônica. 

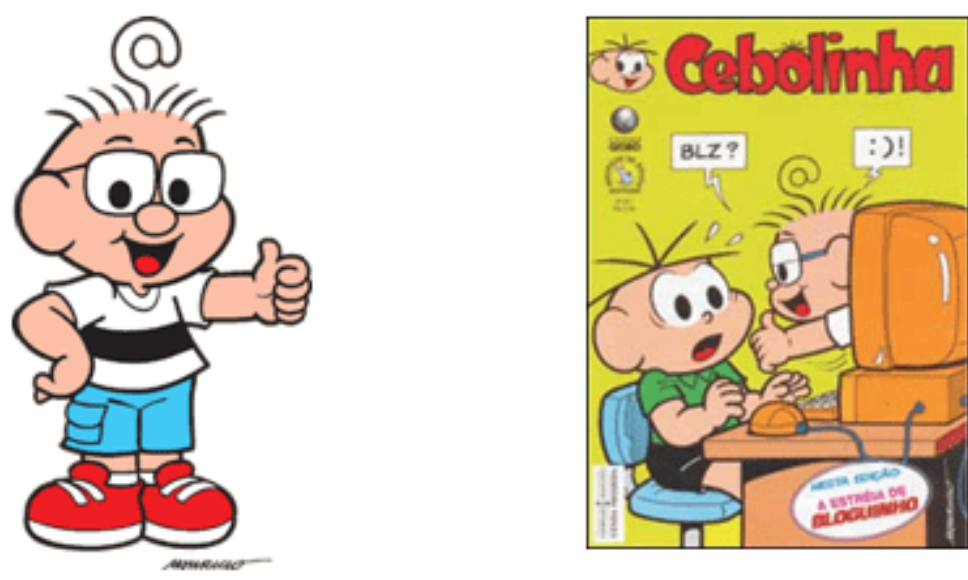

Fonte: Autor.

Mesmo aqueles que já vivem a realidade do "internetês", certamente irão aprovar este toque bem-humorado de inovação dos personagens da Turma da Mônica. E, para aqueles que, assim como o Cebolinha e o Cascão, ainda vêem o "internetês" como algo estranho, será uma portinha de entrada para a familiarização com as expressões dessa linguagem da "era digital da comunicação". (Bloguinho traz o "internetês para o universo das historinhas da Turma da Mônica, op. cit).

A criação de Bloguinho permitiu, na época, uma interface dos quadrinhos para traduzir aos leitores a típica linguagem emprega em salas de bate-papo, ICQ, Messenger, email de adolescentes.

\subsection{CAMPANHA PARA INCENTIVAR A ESCREVER CORRETAMENTE}

Um grupo se reuniu para realizar uma verdadeira campanha em defesa da língua portuguesa a fim de melhorar a escrita em sites abertos na internet, e dessa forma reduzir o uso do enigmático do internetês em sites de muita visitação, como fóruns, blogs, e outras comunidades do gênero. A campanha é intitulada como "Eu sei escrever" criada pela comunidade tecnológica mais ativa do Brasil que se autodenomina como Fórum PCs. 
O escritor Deonísio da Silva, em seu artigo "Do internetês ao português: a volta do filho pródigo", teceu elogios ao Fórum PCs pela capacidade que tiveram para resolver, com novos modos, os velhos problemas e advertiu que:

Inconformados com o internetês, tema deste Observatório, aqui e na televisão, um grupo de jovens deu uma resposta criativa. A novidade está em Eu Sei Escrever. É empreendimento de um grupo de jovens inconformados com os abusos do internetês, sendo o mais grave querer impor o recurso dos torpedos dos celulares, eficientes como recados rápidos, como língua única, capaz de atender a todos os altos objetivos de um sistema complexo como é uma língua, para cuja estruturação a Humanidade consumiu séculos! (DA SILVA, 2006, p.1)

A comunidade do Fórum PCs inconformada com o que chama de "analfabetismo virtual" para os meios de comunicação tradicionais criou e disponibilizou a primeira versão, ainda em fase experimental, do tradutor online de internetês para o português.

Couto explica que a ideia começou porque a diferença de linguagem entre as gerações impedia a troca de informações. "Além do conflito de interesses, há um conflito de linguagem. Os redatores e moderadores do Fórum não entendiam as mensagens. Então foram instruídos a orientar os autores para que escrevam de forma mais clara." "Acho um absurdo", disse Couto, inconformado. "Aos poucos essa linguagem vai complicar os sistemas de busca e não sei até que ponto isso é saudável para o Brasil." (FERRAZ, op. cit, p.1).

Foi criado também um fórum de discursão composto por uma equipe de redatores e moderadores que estão dispostos a orientar os autores de mensagens de conteúdo ininteligível para que escrevam de forma mais clara. $O$ filtro tenta reduzir a quantidade de erros propositais em suas 65 áreas de discussão, onde já foram publicados mais de um milhão de mensagens nos três anos de existência do site. (JULIO, 2006).

O funcionamento é bastante simples e consiste na troca de palavras baseado em um dicionário (uma tabela com os termos conhecidos e suas respectivas traduções) que poderá ser aprimorado com a colaboração de todos os usuários. O filtro é configurado 
para exclusivamente impedir o uso de termos impróprios, os quais serão substituídos automaticamente. Portanto, há permuta das abreviaturas mais comuns pelas palavras correspondentes, transformando "9idade" em "novidade", "naum" em "não" e assim por diante. As palavras retificadas são destacadas com uma cor ou em itálico, a fim de que os autores percebam que estão escrevendo errado.

O criador do site, Paulo Couto afirmou que quando lançou a campanha no fórum algumas pessoas haviam afirmado que continuariam a escrever como queriam, porém, após tanta crítica dos próprios colegas, porque a palavra ficava em vermelho, passaram a escrever certo. (FERRAZ, op. cit).

O Fórum PCs conseguiu ganhar notoriedade e credibilidade e foram convidados para gravar entrevista para a Band, entraram no portal Elnet, no blog Cat Eyes e em apenas dois dias já tinham 350 integrantes na comunidade aberta no Orkut para defender a língua portuguesa e combater o internetês. (DA SILVA, Ibid).

Para incentivar novos adeptos foram até criados selos para a campanha "Eu sei escrever", os quais podem ser utilizados pelos usuários que buscam escrever segundo a norma culta da língua portuguesa. A comunidade do Fórum PCs é atualmente a melhor do Brasil e a $36^{\circ}$ mais atuante do mundo. (JULIO, op. cit). Ela convida as pessoas a se filiarem à campanha, que tem até comunidade no site de relacionamentos Orkut, para tanto basta que o interessado acesse a página www.euseiescrever.com.br.

A seguir, pode-se visualizar os selos da campanha "Eu sei escrever".
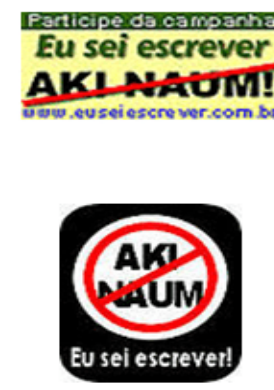

Fonte: Flickr, 2019
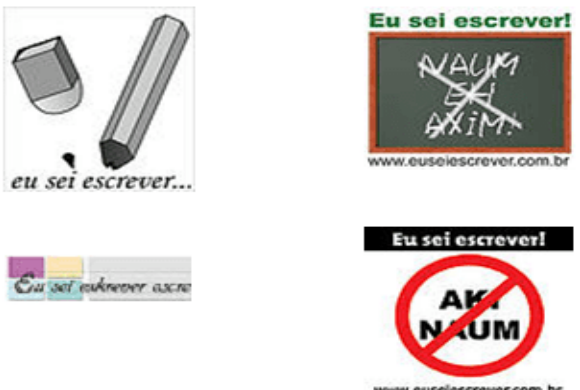


\subsection{O INTERNETÊS NA SALA DE AULA}

O internetês pode ser um ótimo pretexto para que os docentes conquistem a atenção dos seus educandos para discutir a língua propriamente dita. (MARCONATO, op. cit). Ele já rompeu o limite das telinhas de computador e televisão, ultrapassou também os limites do rádio e chegou as escolas e já foi tema de concurso público.

O Núcleo de Eventos e Concurso incluiu o internetês como tema da prova, no dia 07 de maio de 2006, para o preenchimento de vagas para o cargo de terapeuta ocupacional na Universidade Federal do Maranhão. O texto "A revolução do internetês" foi extraído da Revista Língua Portuguesa, ano I, número 5 de 2006. E foram elaboradas dez questões explorando o assunto.

Para entender a peculiaridade do internetês e determinar o momento em que o uso pede grafia tradicional ou jargão, duas escolas paulistanas se uniram num projeto ousado. O Colégio Humboldt, uma escola particular, e a Escola Municipal Heitor Penteado propiciaram também uma reflexão sobre a desigualdade social. (MARCONATO, Ibid)

Os alunos do Colégio Humboldt tiveram a missão de escrever bilhetes, usando internetês, para os alunos do Heitor Penteado. Ao receberem e lerem os bilhetes, muitos alunos não foram capazes de compreender o que estava escrito. Fato compreensível, pois os discentes da escola municipal não tinham acesso a computador e não conheciam o internetês.

É mister frisar que a pequena amostra da pesquisa vai ao encontro do fato de que no Brasil a maioria da população não usa computador e 3 milhões dos 10 milhões de habitantes de São Paulo não estão familiarizados com ele, portanto, o internetês é diretamente proporcional à inclusão digital.

O projeto dos professores de português permitiu mostrar aos alunos que o idioma virtual não é proibido, mas deve ser usado no ambiente adequado, que é a internet, e jamais nas tarefas e trabalhos acadêmicos. (MARCONATO, Ibid) 
É mister ressaltar que cabe aos professores manter a atenção quanto a linguagem utilizadas pelos discentes e, caso se perceba a dificuldade entre a grafia da língua portuguesa e o internetês, o docente deverá alertá-lo para o correto momento no qual o aluno deverá empregar essa forma mais informal de linguagem.

\subsection{EXEMPLOS DE COMUNICAÇÃO USANDO O INTERNETÊS}

Os usuários da Internet simplificam as suas palavras e expressões através de verdadeiros neologismos. Eles ousam, criam, dia a dia, a despeito de qualquer norma gramatical, seus próprios vocábulos, encurtando palavras, tirando acentos e pontuações, Internetesiando até brocardos e/ou expressões estrangeiras, já dantes aportuguesadas.

Para exemplificar abaixo estão transcritas a conversa retirada de uma sala de batepapo.

Chester Bennington, do Linkin Park, o baixista do The Offspring, Greg K, e integrantes do Bad Religion, Crazy Town e Orgy, estão entre os roqueiros de bandas que vão trocar seus instrumentos por tacos de golfe. Eles vão participar do campeonato de golfe para caridade Punk Rock Pro-Am, que rola nesta sexta-feira em Jamul, na Califórnia. Vários fãs deram lances pra jogar com os caras, e quem conseguiu o mais alto - de US\$525 - foi Chester, que vai contar também com a ajuda do Ryan Shuck, guitarrista do Orgy. O evento vai arrecadar dinheiro para as ONGs Surfrider Foundation e Music for a Cure.

\section{Comentários ( 6 )}

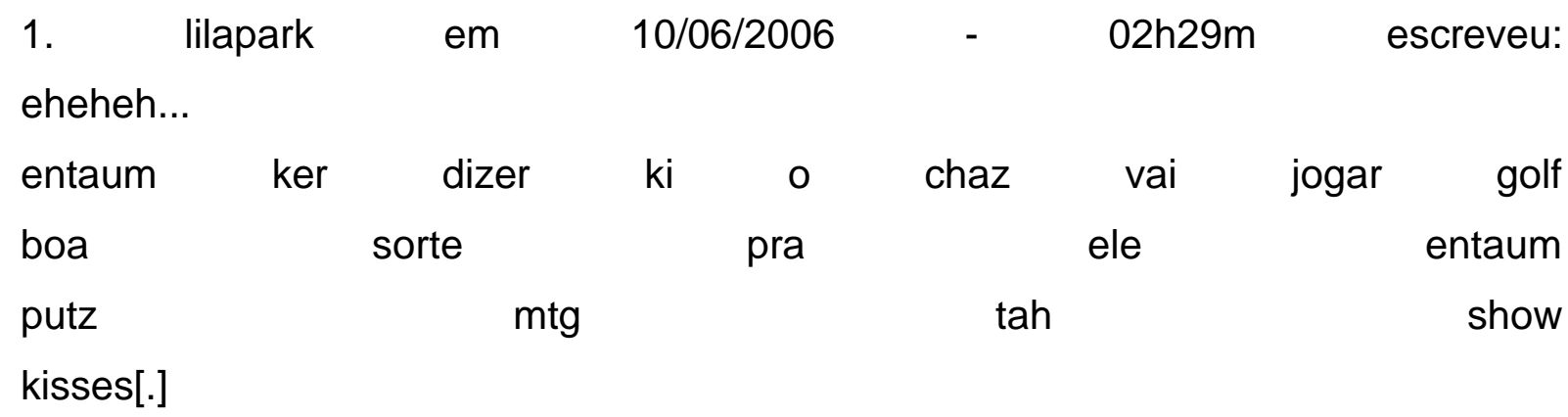


2. roblp4ever em 10/06/2006 - 08h20m escreveu: 00000

chester

jogando

golf

srsrs

sera

q

ele

bom

nisso??

deve

e ser

ta

show

a

$\mathrm{mtg}$ dele

arsando

[x]Maycol Bourdon[x]

3. rarah em 10/06/2006 - 09h53m escreveu:

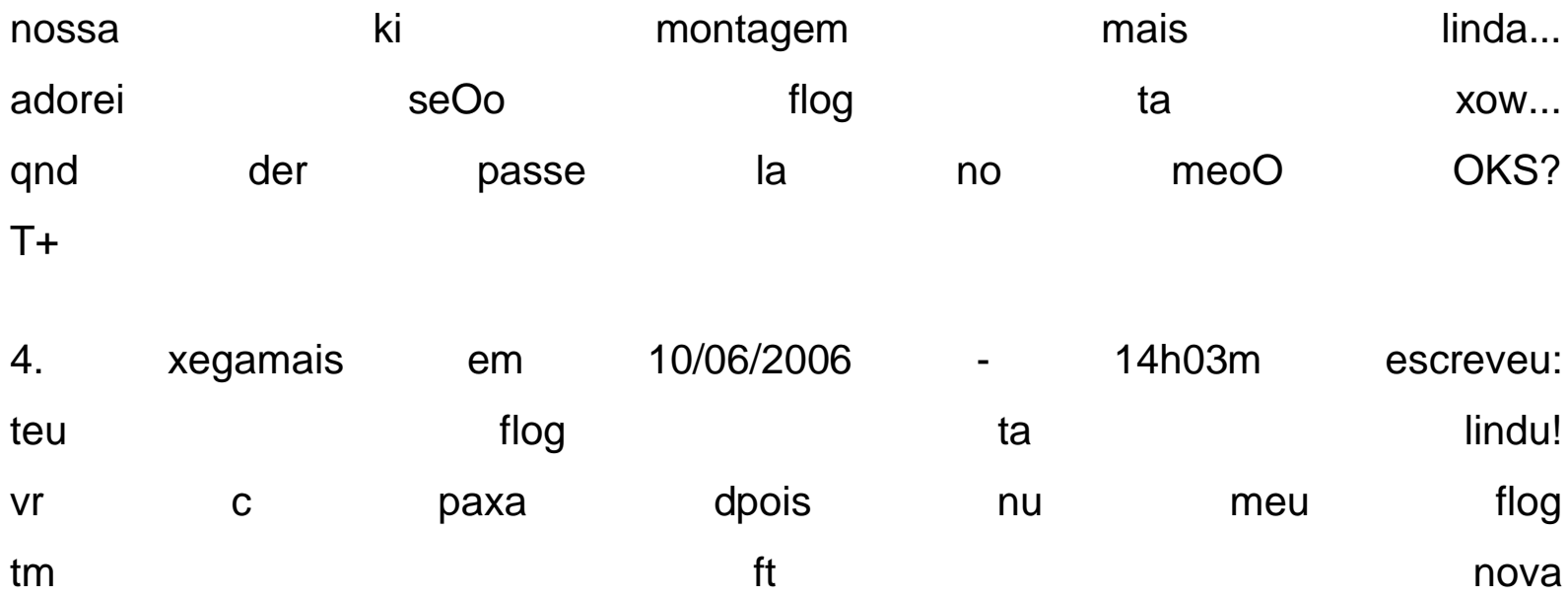

xau

5. crazyformikeshinoda em 10/06/2006 - 15h25m escreveu: OIE...SEU FLOG TÁ LINDU... A MONTAGEM FICOU SHOW!!! PASSA LÁ DEPOIS FOTINHA NOVA.. BJUSSSSSSSSS.

6. thaizinharock em 10/06/2006 - 17h35m escreveu: Oie Td

$\mathrm{Blz} ? ? ?$ Putz tah xou a ft amo 0 chazy $\mathrm{mt}$ lindexxx seu flog está mt foda tipow qdo

d

passa

lah 
post

novo

bjão

pra

fui.

Como se pode constatar nas transcrições anteriores, os usuários do internetês conseguem se comunicar de forma efetiva a desta forma atende ao sentido real da comunicação, a transmissão e compreensão da mensagem. No entanto, sabe-se que houve discussão sobre os impactos negativos que esse fenômeno linguístico poderia gerar na aprendizagem da já fragilizada escrita correta da língua. Por isso, o seu emprego divide opiniões entre especialistas. Os que consideram o sentido literal da ortografia como a escrita correta das palavras tentem a rejeitá-lo. Todavia, ele como forma de expressão no mundo virtual representa uma espécie de revolução, visto que os (inter)locutores podem trocar informações com o mundo todo numa velocidade imediata. (SILVA, 2014).

\section{CONCLUSÃO}

O advento da internet trouxe para a realidade brasileira uma série de palavras e expressões, em configuração de comandos ou aplicações, muitas sem apropriado significado em nossa língua. Todavia, ela também foi um caminho para o surgimento de um novo idioma, o internetês.

O internetês é um sistema grafolinguístico formado por abreviações de palavras já na forma coloquial do português e por um conjunto de caracteres disponíveis nos teclados dos computadores. O objetivo do idioma virtual foi acelerar o processo de escrita a fim de se tornar compatível com a velocidade das mensagens instantâneas, além de tornar a escrita menos pessoal, mais descontraída e próxima da oralidade.

Muitos acreditam que a linguagem peculiar dos jovens na internet passou a influência na escrita em sala de aula e este fato começou a preocupar os educadores. Há aqueles que afirmam que a nova linguagem é uma ameaça as normas gramaticais da Língua Portuguesa, pois as abreviaturas e ícones costumam aparecer em anotações de aulas e redações. 
É bem verdade que o idioma virtual não respeita as normas ortográficas, deforma o léxico, destrói o sistema oficial de abreviaturas, revoga a pontuação e a acentuação em nome da fonética das palavras e não mais da etimologia, logo esse linguajar é um sinal da perda da identidade linguística.

Para outros educadores, o idioma virtual não é preocupante. Ele representaria apenas é o desejo de informalidade, isto é, de fazer com que a língua escrita se torne o mais parecido possível com a língua falada informal.

Alguns críticos do internetês asseguram que os textos produzidos no mundo virtual são ruins. $E$ às vezes, o são, porém, será que os textos seriam melhores se fossem escritos em grafia oficial? E se os jovens não participassem de sessões de bate-papo? Sintetizando, o texto ruim em internetês não fica mais perfeito em grafia tradicional, se for só essa a mudança.

A língua escrita e quase falada dos internautas é mais uma das inúmeras variantes de uso de nossa língua. Portanto, o internetês não está descaracterizando a Língua Portuguesa, mas apenas está incorporando ao idioma novos termos.

Não há dúvida de que esse segmento poderá influir nas futuras transformações pelas quais a língua irá passar nos próximos anos. Porém isso não significa deterioração, mas evolução do idioma.

O novo sistema grafo linguístico vem agilizar o processo de comunicação em tempo real, por isso é que existe um amplo uso de abreviaturas e ícones, além do fato das perguntas e respostas serem mais curtas e muito mais parecidas com a linguagem oral. Neste sentido, o internetês realmente representa uma evolução no sistema de comunicação, mas só o tempo dirá os efeitos deletérios ou os benefícios que essa evolução causará.

\section{REFERÊNCIAS}

BAGNO, Marcos. Português ou brasileiro? um convite à pesquisa. 5. ed. São Paulo: Parábola Editorial, 2005. $184 \mathrm{p}$. 
BAGNO, Marcos. Preconceito linguístico: o que é, como se faz. 43. ed. São Paulo: Loyola, 2006. $186 \mathrm{p}$.

Bloguinho traz o "internetês para o universo das historinhas da Turma da Mônica. Disponível em: http://www.monica.com.br/mural/bloguinho.htm. Acesso em: 20 jul. 2006.

BRYAN, Guilherme. Emoções preconcebidas, São Paulo, a.1, n. 5, p. 27-29, mar. 2006.

Código virtual. Disponível em: http://revistaepoca.globo.com/Epoca/0,6993, EPT1036232-1664,00.html. Acesso em: 28 jul. 2006.

DA SILVA, Deonísio. Do internetês ao português: a volta do filho pródigo. Disponível em: http://observatorio.ultimosegundo.ig.com.br/artigos.asp?cod=333ENO001. 13 jun. 2005. Acesso em: 20 jul. 2006.

DIESEL, Úrsula. A nossa língua na nova mídia. Disponível em: http://www.uniceub.br/periodicos/finosleitores/3/artigoursula.asp. Acesso em: 01 ago. 2006.

ECHEVERRIA, Malu. Revistacrescer.globo.com, Linguagem da internet: você fala internetês? Disponível em: http://www.globo.com/Crescer/0,19125,EFC886442-22162,00.html. Acesso em: 02 ago 2006.

ELIO. Noticiário Geral, Nossa sugestão para o internetês. 03 dez 2005. Disponível em:

http://www.internetopolis.com.br/news.php?cod=60\&PHPSESSID=f1d7cfc81af8339d 8aba2699126bd8b6. Acesso em: 01 ago. 2006.

FARACO, Carlos Alberto. Estrangeirismos e a antropofagia brasileira. Biblioteca entre Livros, São Paulo, a.1, n. 4, p. 90-93, jun. 2006. 
FERRAZ, Claudia. O Estado de São Paulo, uma campanha pelo fim do "naum". 09 jun 2006. Disponível em http://www.puccamp.br/servicos/detalhe.asp?id=9740. Acesso em: 15 jul. 2006.

FILHO, Paulo Bearzoti. O internetês é inofensivo e inventivo. Discutindo Língua Portuguesa, São Paulo, a.1, n. 2, p. 32, mar./abr. 2006.

GRESPAN, Gilmar. O uso da língua portuguesa escrita em tempo real na internet. 1998. 25 f. Monografia (Especialização em Estudos Avançados de Língua Portuguesa e Linguística). Faculdade de Educação, Ciências e Letras Urubupungá, Faculdades Integradas Urubupungá. São Paulo, Pereira Barreto.

HAMZE, Amelia. Internetês. Brasil Escola. Disponível em: https://educador.brasilescola.uol.com.br/trabalho-docente/internetes.htm. Acesso em: 31 jul. 2019.

HAMZE, Amelia. Pesquisa na Internet. Disponível em http://lousadigital.blogspot.com/ Barretos. Acesso em: 20 jul. 2006.

HANSEN, Karla. Internetês: ameaça à língua portuguesa. Disponível em: http://www.educacaopublica.rj.gov.br/jornal/materia.asp?seq=227. 11 abr. 2005. Acesso em: 12 jun. 2006.

INAGAKI, Alexandre. Enlouquece, Pense Nisso. Disponível em: http://www.gardenal.org/inagaki/2005/12/bloguinho_e_a_questao_dos_cred.html. Acesso em: 12 jun. 2006.

JULIO. Campanha "Eu sei escrever": incentiva a escrita correta na internet. Disponível em: http://euseiescrever.blogspot.com/. Acesso em: 01 ago. 2006.

KOMESU, Fabiana e TENANI, Luciani. Considerações sobre o conceito de "Internetês" nos estudos da linguagem. Linguagem em (Dis)curso, Palhoça, SC, v. 9, n. 3, p. 621-643, set./dez. 2009

KOMESU, Fabiana. O internetês na escola. São Paulo: Cortez, 2015. 
LEMOS, Ana Cristina et al. Linguagem da Internet. Coleção Gira Mundo, São Paulo, n. 11, p. 1-4, mar./abr. 2003.

LEONEL, Fernanda. Internetês: Certo ou errado? O que se sabe é que essa linguagem já virou mania entre a galera web! 18 jan 2006. Disponível em http://www.acessa.com/informatica/arquivo/galeraweb/2006/01/18-internet/. Acesso em: 30 jul. 2006.

LINKINSALES. Curso de Língua Internetês. Disponível em http://www.flogao.com.br/linkinsales/news/239378 > 25 mar. 2005. Acesso em: 10 jul. 2006.

MARCHELLI, P. S.; SILVA, Direu da. O que é a internet ? Ciência \& Ensino: UNICAMP, São Paulo, n. 4, p. 3-9, jun. 1998. Disponível em: http://www.fisica.ufc.br/conviteafisica/cien_ens_arquivos/numero4/p03.pdf. Acesso em: 03 ago. 2006.

MARCONATO, Silvia. A revolução do internetês. Discutindo Língua Portuguesa, São Paulo, a.1, n. 5, p. 22-26, mar. 2006.

MESSBRASIL CIDADE INTERNET. Emoticons. Disponível em: http://messbrasil.cidadeinternet.com.br/emoticons/atualizados.htm. Acesso em: 01 ago. 2006.

MORAES E SOUZA, Adalto. Guia de Reforma Ortográfica. São Paulo: Museu da Língua Portuguesa: FMU, 2013.

O SUL. Função do WhatsApp vira 'febre' no mundo. O Sul: Caderno 1, Notícias, Tecnologia. 16 de setembro de 2018. Disponível em: http://www.osul.com.br/funcao-do-whatsapp-vira-febre-no-mundo-veja-ascuriosidades/. Acesso em: 31 jul. 2019. 
O WEBLOG DA ACGLOBA.Filmes em internetês. Disponível em: http://blog.accomunica.com/acblog.php/2005/03> 29 mar. 2005. Acesso em: 20 jul. 2006.

POSSENTI, Sírio. Você entende internetês? Discutindo Língua Portuguesa, São Paulo, a.1, n. 2, p. 28-33, mar./abr. 2006.

SILVA, Anderson Cristiano da. As implicações do internetês na ortografia: um estudo em duas escolas públicas paulistas. Revista Letras Raras, [S.I.], v. 3, n. 1, p. 93-107, set. 2014. ISSN 2317-2347. Disponível em: http://revistas.ufcg.edu.br/ch/index.php/RLR/article/view/231. Acesso em:31 jul. 2019. doi:http://dx.doi.org/10.35572/rlr.v3i1.231.

SILVINO, Leonardo. A novilíngua, a sua nova língua. Disponível em: http://www.duplipensar.net/george-orwell/novilingua-sua-nova-lingua.html. 03 fev. 2006. Acesso em: 28 jul. 2006.

TV E BRASIL - Programa do dia. Linguagem de internet. Disponível em: http://www.tvebrasil.com.br/observatorio/arquivo/principal_050329.asp. 29 mar. 2005. Acesso em: 12 jun. 2006.

WIKIPÉDIAa, A ENCICLOPÉDIA LIVRE. Internetês. Disponível em: http://pt.wikipedia.org/wiki/Internet\%C3\%AAs. Acesso em: 20 jul. 2019.

WIKIPÉDIA ${ }^{b}$ A ENCICLOPÉDIA LIVRE. Linguagem humana. Disponível em: http://pt.wikipedia.org/wiki/ldioma. Acesso em: 20 jul. 2019.

Enviado: Agosto, 2019.

Aprovado: Setembro, 2019. 